\title{
The Dimensions of Ethical Leadership Delineated by Codes of Ethics for Executives and Financial Officers
}

\author{
Harlan Etheridge (Corresponding author) \\ Associate Professor, Department of Accounting \\ B. I. Moody III College of Business Administration \\ University of Louisiana at Lafayette \\ P.O. Box 43658, Lafayette, LA 70504-3658, US \\ E-mail: harlan@louisiana.edu \\ Kathy Hsiao Yu Hsu \\ Associate Professor, Department of Accounting \\ B. I. Moody III College of Business Administration \\ University of Louisiana at Lafayette \\ P.O. Box 43658, Lafayette, LA 70504-3658, US
}

Received: October 13, 2018 Accepted: December 29, 2018 Published: January 7, 2019

doi:10.5296/ijafr.v9i1.14053

URL: https://doi.org/10.5296/ijafr.v9i1.14053

\begin{abstract}
The financial scandals of the late 1990s and early 2000s led Congress to pass the Sarbanes-Oxley Act of 2002 (SOX). SOX Section 406 requires publicly-traded corporations to disclose whether they have a separate code of ethics that applies to their senior financial officers (financial code of ethics). Our study examines the content of the financial code of ethics of 29 publicly-traded firms and find that, in accordance with SOX 406, full, fair, accurate, timely and understandable disclosures and compliance with applicable laws and regulation are strongly encouraged by these codes of ethics as are and honest and ethical conduct and communication of issues by the senior financial officers. Most of the codes we examine also expect their senior financial officers to be positive role models for other employees and to actively promote ethical behavior. Most of the financial codes of ethics we
\end{abstract}


examine also prohibit certain activities, primarily conflicts of interest and insider trading. The majority of the codes also specify penalties for violations of the codes with most of the codes listing termination of employment and other disciplinary actions in response to code violations. Most of the codes also contain provisions that require senior financial officers to report any violations of the code of ethics of which they are aware. We are surprised to find that many of the codes do not discuss important issues. For example, the issues of waivers of the code of ethics or prohibition of retaliation for reporting code violations are discussed only by a minority of the codes in our study. Similarly, less than half of the codes in our study require officer signatures or certification and less than a third discuss the process for amending the code of ethics. Finally, very few codes provide guidance for officers who seek clarification of the code, discuss who within the company is considered the "owner" of the code, or disclose where interested parties can locate the code.

Keywords: Ethics, Code of conduct, Senior financial officers, Sarbanes-Oxley, SOX 406

\section{Introduction}

In the early 2000s, we witnessed the consequences of poor ethical leadership as evidenced by corporate actions that resulted in the financial scandals of Enron, WorldCom, Tyco, etc. In each of these cases, the lapse in ethical leadership occurred at the highest levels of the organization and the means of perpetuating fraud was often engineered by those officers who were responsible for corporate financial records and disclosures. To restore investor confidence in corporate disclosures and in the financial markets, Congress passed the Sarbanes-Oxley Act (SOX) of 2002 that not only expanded regulatory oversight and guidance for auditors, lawyers, and analysts, but also addressed many corporate governance matters. In particular, section 406 of the Sarbanes-Oxley Act (SOX 406 hereafter) specifically requires companies whose stock is listed on U.S. stock exchanges (Note 1) to disclose whether or not they have adopted a code of ethics for their senior financial officers that applies to their principal financial officer and controller or principal accounting officer, or persons performing similar functions. SOX 406 further requires companies that have not adopted such a code of ethics to explain why they have not done so.

A code of ethics is a formal statement that provides guidance for individual actions, particularly in ethically-challenging situations. The importance of having a formal code of ethics in a business organization is well-documented in the literature (Fisher 2003, Preuss, 2010). Prior studies that analyze the content of corporate code of ethics find that corporate codes of ethics vary across companies because of cultural and industry differences (Sharbatoghlie, Mosleh, \& Shokatian, 2013). Research also has shown that corporate codes of ethics evolve with the same company over time due to environmental changes such as social events, cultural, economic and regulatory changes (Murphy, 1989) Chryssides and Kaler 1996, (Wood, 2000), Crane and Matten 2004, (Sharbatoghlie et al., 2013)).

A code of ethics statement that is specifically written for and applies to top executives and financial officers (herein after referred to as a financial code of ethics) is an example of how corporate codes of ethics evolve over time. We believe that most of the financial codes of ethics of U.S. corporations are likely responses to comply with SOX 406. Although these 
financial codes of ethics probably contain some similarities due to the requirements of SOX 406 (and other sections of SOX), it also is likely that the financial codes of ethics will vary to a certain degree because of differences across industries and differences in corporate cultures. The purpose of this study is to investigate the financial codes of ethics of a sample of corporations traded on U.S. stock exchanges and identify the commonalities and unique aspects of these codes. Such an investigation will give some insight into the levels of importance assigned by corporations to the various ethical responsibilities of their executives and finance officers.

\section{Prior Research}

Research on corporate codes of ethics/conduct encompasses several topical areas. Our study is primarily concerned with the content analysis of the financial codes of ethics, so the following literature review focuses on previous studies that examine the content of general corporate codes of ethics/conduct. Our discussion of prior research in this area focuses on behavior related to corporate financial responsibilities to provide a linkage between the historical development of general corporate codes of ethics/and corporate financial codes of ethics.

The Opinion Research Corporation (1980) surveyed U.S. corporations about their codes of conduct and found that these codes, in general, are revised only when laws or regulations that affect the corporations change. Their results also indicate that enforcement of the code usually is the responsibility of an upper-level corporate officer, the audit committee of the board of directors or corporate legal counsel. Violations of the code usually are required to be reported to a specific corporate officer or committee, but the codes seldom discuss penalties for code violations.

White and Montgomery (1980) conducted a study of general corporate codes of conduct and sent surveys to two thousand U.S. corporate CFOs. Their survey has a response rate of approximately $34 \%$ (673 responses). They found that the majority (77\%) of the respondents' companies had written codes of conduct and that almost all of the corporations distributed the codes to officers and key employees; however, slightly more than a majority (55\%) of the corporations distributed the codes to lower-level employees (White \& Montgomery, 1980). The authors also performed a content analysis of a random sample of 30 of the codes of conduct of the responding corporations. The results of their content analysis indicated that most of the codes provide a context for the code and a purpose statement. Additionally, they found that a few topics were incorporated in most of the codes: a general statement of ethics and philosophy (80\%), compliance with applicable laws $(67 \%)$, false entries in books and records $(50 \%)$, misuse of corporate assets (50\%), conflicts of interest (73\%), insider information (63\%) and confidentiality of information (40\%).

Another study that examined corporate codes of conduct/ethics is Cressy and Moore (1983). The authors of this study examined the corporate codes of ethics/conduct and related documents that were deposited at the Conference Board's library in the mid-1970s. Of the 249 documents that were available, 119 were usable. They found that the majority of the codes they examined (69\%) discussed conflicts of interest; however, the integrity of books 
and records (Note 2) was discussed in general by less than half of the codes $(49.1 \%)$ and discussed in detail by only $13.8 \%$ of the codes. Very few codes (16.4\%) contained discussion of white-collar crimes, e.g., embezzlement. Approximately $75 \%$ of the codes discussed enforcement of the code while only $42 \%$ discussed code violations and related sanctions. Very few of the codes, less than $10 \%$, contained a section regarding the responsibility for deciding the guilt or innocence of potential code violators and what sanctions would be appropriate for those who are found guilty.

Benson (1989) reviewed the codes of conduct of 155 U.S. corporations and found that $60 \%$ discussed insider trading, 75\% discussed conflicts of interest and about 1/3 of the codes discussed accounting records. He also suggested ways to improve the usefulness of corporate codes of conduct/ethics:

The reason(s) for each item included in the code should be explicitly stated in the code.

Codes need beginnings and conclusions which attempt to secure the collective support of employees to keep the corporation's actions "above board."

Codes should recognize the responsibilities of management in addition to the responsibilities of employees.

Codes should be publicized more so that the public will appreciate the corporation more.

The usefulness of codes depends on the support of boards of directors and top management.

Wood (2000) performed a cross-cultural comparison of the contents of the codes of ethics of three countries: the U.S., Canada and Australia. He found that in all three countries, employee conduct detrimental to the firm is mentioned much more frequently in the codes than employee conduct beneficial to the firm. Further examination revealed that codes in the U.S., Canada and Australia vary in their discussion of conflicts of interest $(75.3 \%, 93.3 \%$ and $72.3 \%)$, confidentiality of information $(45.1 \%, 81.3 \%$ and $67.5 \%)$, insider trading $(43.1 \%, 72 \%$ and $56.6 \%)$, and integrity of books and records $(75.3 \%, 82.7 \%$ and $57.8 \%)$.

Lugli, Kocollari and Nigosolari (2009) examined the codes of ethics of forty publicly-traded Italian corporations. They found that the vast majority of the codes (72\%) contained provisions related to transparency, true and complete reporting, communication and bookkeeping and that $55 \%$ of the codes expected covered employees to comply with laws and regulations. A greater proportion of the codes addressed more general aspect of ethics: honesty $(86 \%)$ and integrity $(83 \%)$. Less than half of the codes $(43 \%)$ expected impartiality and independence in decision making. The majority of these codes also had sections concerned with corruption (86\%), confidentiality of information (97\%), and conflicts of interest (86\%). Most of these codes covered implementation of the code $(65 \%)$, employee reporting of code violations and prevention of retaliation against whistle-blowers (69\%), and sanctions against violators (59\%).

Singh (2006) conducted a longitudinal study of the codes of ethics of Canada's largest corporations. He found that the percentage of codes that addressed the acceptance of bribes and kickbacks and the payment of bribes and kickbacks decreased from 1992 to 2003 (82.7\% 
to $79 \%$ and $66.7 \%$ to $61 \%$, respectively). Similarly, the percentage of codes that covered conflicts of interest $(95.3 \%$ to $85 \%)$, confidentiality of information $(81.3 \%$ to $81 \%)$, insider trading (72\% to $70 \%)$, and the integrity of books and records $(82.7 \%$ to $64 \%$ ) all decreased from 1992 to 2003. Notable exceptions to these declines are the percentage of codes mentioning enforcement or compliance proceedings (70.7\% to $86 \%)$ and dismissal or firing as a sanction for code violation ( $46.7 \%$ to $58 \%)$.

The aforementioned studies focus on the purpose and content of general corporate codes of ethics. Our study differs in that it focuses on corporate codes of ethics for the principal executive officer and senior finance officers as suggested by SOX 406. Other recent studies focus on other aspects of a firm's code of ethics. A sample of these studies is presented below.

Garegnani et. al (2015) investigated the impact effected on a firm's code of ethics by the role of the primary shareholders within the firm, the role and influence of independent directors on the board, the effect of board size on the strategic decision-making process and the influence of the chief executive officer's age and gender diversity. Their sample of firms encompassed 248 Italian public companies having a published code of ethics in 2011. They found that codes of ethics are strongly influenced by the ownership structure of the company with shareholders with larger stakes having greater influence on the quality of a code. Their results also indicated that the lower the number of independent directors, the higher the tendency that a firm will have a higher quality code of ethics. Likewise, they found that firms with smaller boards of directors and younger CEOs are more likely to have higher-quality codes of ethics.

Adelstein and Clegg (2016) examined the code of ethics of Microsoft Corporation using genealogical discourse analysis in an attempt to understand how management frames expectations of compliance. They found that employees are treated differently according to their risk profile and concluded that expectations that ethical behavior of employees align with organizational values listed in the code of ethics were different for finance and legal employees. They suggested that these employees were not viewed as the subjects of organizational compliance, but rather, along with executive management, the managers of ethics and the gatekeepers of the code.

Finally, another recent study examined a singular aspect of SOX 406. Ahluwalia et. al (2018) investigated the impact of a financial code of ethics on financial reporting for a sample of 176 firms from 2005 - 2011. They used financial restatements as a measure of improved financial reporting and found that the adoption of a financial code of ethics by a firm improved the integrity of financial reporting, in that firms with a financial code of ethics were more likely to voluntarily restate financial statements, when necessary, instead of being subject to SEC action to force a restatement.

The remainder of our paper is organized as follows. Section 3 discusses the data and method used in our study, section 4 discusses our results and section 5 presents our conclusions. 


\section{Data and Method}

The financial codes of ethics were obtained from the websites of 29 publicly-traded U.S. corporations. These corporations encompass 29 industries, range in size from $\$ 2,406$ million to $\$ 113,481$ million in assets and employ between 3,000 and 360,000 employees. Refer to Appendix 1 for a listing of the companies included in our study.

All of the financial codes of ethics were imported into NVivo 11 Plus qualitative data analysis software. A basic set of potential "nodes" was initially identified, with each "node" representing a specific topic or concept within the financial codes of ethics. Both researchers in this study then began associating the text of the financial codes of ethics to these nodes. New nodes were added, as needed, as the financial codes of ethics were processed. Eventually, we had 225 nodes in NVivo for this study.

Once all of the financial codes of ethics were processed, we ran statistics on the financial codes of ethics. These statistics consisted of the number of occurrences of topics or concepts related to each node across the 29 financial codes of ethics and the percentage of the text that each node represented relative to the total text that was processed. Our results are detailed in the following section.

\section{Results}

SOX 406 defines the term "code of ethics" as standards that are reasonably necessary to promote:

(1) Honest and ethical conduct, including the ethical handling of actual or apparent conflicts of interest between personal and professional relationships;

(2) Full, fair, accurate, timely, and understandable disclosure in the periodic reports required to be filed by the issuer; and

(3) Compliance with applicable governmental rules and regulations.

Consequently, we expect that most of the financial codes of ethics we review will contain sections devoted to these areas. However, we find that most of the financial codes of ethics examined in our study go far beyond these three SOX 406 suggestions. Our study identifies fourteen major categories (nodes) within the twenty-nine financial codes of ethics in our study:

Title, Covered Employees, Purpose, Officer Responsibilities, Guidance for Officers, Prohibited Activities, Consequences of Violations, Reporting Code Violations and Asking Questions About the Code, Prohibition on Retaliation for Reporting Code Violations, Code Amendments, Code Waivers, Officer Signature or Certification, Code Availability, and Code Ownership.

Table 1 lists the fourteen major categories of the codes with their most referenced level-1 subcategories along with the number of references associated with each category and level-1 subcategory. The major code categories are listed in order of decreasing occurrence across the codes, i.e., the categories that appear in all of the codes are listed first, followed by the 


\section{Mll Macrothink}

International Journal of Accounting and Financial Reporting

ISSN 2162-3082 2019, Vol. 9, No. 1

categories that appear in most of the codes, etc. The level-1 subcategories within each category also are listed in decreasing occurrence across the codes. We do not list all level-1 subcategories, but limit the list to those that are referenced in at least four of the twenty-nine codes of ethics we examine.

Table 1. Major financial code of ethics (FCOE) categories and the most common level-1 subcategories

\begin{tabular}{|c|c|c|c|c|c|}
\hline $\begin{array}{l}\text { Major Code } \\
\text { Categories }\end{array}$ & $\begin{array}{l}\text { \# of FCOE } \\
\text { Containing }\end{array}$ & $\begin{array}{l}\# \quad \text { of } \\
\text { References }\end{array}$ & $\begin{array}{l}\text { Level-1 } \\
\text { Subcategories }\end{array}$ & $\begin{array}{l}\text { \# of FCOE } \\
\text { Containing }\end{array}$ & $\begin{array}{l}\# \text { of } \\
\text { References }\end{array}$ \\
\hline FCOE Title & 29 & 29 & & & \\
\hline \multirow{4}{*}{$\begin{array}{l}\text { Covered } \\
\text { Employees }\end{array}$} & \multirow{4}{*}{29} & \multirow{4}{*}{30} & CEO & 27 & 29 \\
\hline & & & $\begin{array}{l}\text { Principal } \\
\text { Accounting } \\
\text { Officer }\end{array}$ & 19 & 20 \\
\hline & & & $\mathrm{CFO}$ & 18 & 20 \\
\hline & & & $\begin{array}{l}\text { Senior Financial } \\
\text { Officers }\end{array}$ & 14 & 15 \\
\hline \multirow{8}{*}{$\begin{array}{l}\text { Officer } \\
\text { Responsibilities }\end{array}$} & \multirow{8}{*}{29} & \multirow{8}{*}{286} & $\begin{array}{l}\text { Full, fair, accurate, } \\
\text { timely and } \\
\text { understandable } \\
\text { disclosures }\end{array}$ & 28 & 32 \\
\hline & & & $\begin{array}{l}\text { Laws, rules and } \\
\text { regulations }\end{array}$ & 24 & 33 \\
\hline & & & $\begin{array}{l}\text { Honest and ethical } \\
\text { conduct }\end{array}$ & 23 & 30 \\
\hline & & & $\begin{array}{l}\text { Communication of } \\
\text { Issues }\end{array}$ & 20 & 145 \\
\hline & & & $\begin{array}{l}\text { Role model and } \\
\text { promoting ethical } \\
\text { behavior }\end{array}$ & 17 & 26 \\
\hline & & & Integrity & 13 & 16 \\
\hline & & & $\begin{array}{l}\text { Comply with this } \\
\text { code }\end{array}$ & 11 & 14 \\
\hline & & & Protecting assets & 10 & 11 \\
\hline
\end{tabular}




\begin{tabular}{|c|c|c|c|c|c|}
\hline & & & $\begin{array}{lr}\text { Responsible } & \text { use } \\
\text { and control } & \text { over } \\
\text { assets } & \text { and } \\
\text { resources } & \end{array}$ & 10 & 10 \\
\hline & & & $\begin{array}{l}\text { Independent } \\
\text { judgment }\end{array}$ & 10 & 10 \\
\hline & & & Confidentiality & 9 & 12 \\
\hline & & & Due care & 9 & 9 \\
\hline & & & $\begin{array}{l}\text { Comply with the } \\
\text { general code of } \\
\text { ethics }\end{array}$ & 7 & 9 \\
\hline & & & Competence & 7 & 7 \\
\hline & & & Diligence & 7 & 7 \\
\hline & & & Good faith & 7 & 7 \\
\hline & & & Internal controls & 6 & 8 \\
\hline & & & $\begin{array}{l}\text { Accounting } \\
\text { treatments }\end{array}$ & 4 & 14 \\
\hline \multirow{4}{*}{$\begin{array}{l}\text { Prohibited } \\
\text { Activities }\end{array}$} & \multirow{4}{*}{25} & \multirow{4}{*}{58} & Conflict of interest & 21 & 22 \\
\hline & & & Insider trading & 13 & 17 \\
\hline & & & $\begin{array}{l}\text { Coerce, } \\
\text { manipulate, } \\
\text { mislead } \\
\text { fraudulently } \\
\text { influence } \\
\text { independent } \\
\text { auditors of CPAs }\end{array}$ & 8 & 9 \\
\hline & & & $\begin{array}{l}\text { Misrepresenting } \\
\text { material facts }\end{array}$ & 6 & 6 \\
\hline \multirow{3}{*}{ Purpose } & \multirow{3}{*}{24} & \multirow{3}{*}{65} & $\begin{array}{l}\text { Supplement the } \\
\text { general COE }\end{array}$ & 13 & 15 \\
\hline & & & $\begin{array}{l}\text { Promote honesty } \\
\text { and ethics }\end{array}$ & 10 & 11 \\
\hline & & & Ensure or promote & 7 & 8 \\
\hline
\end{tabular}


Reporting Code

Violations and

Questions about

20

the Code
29

compliance

laws

regulations

Prevent

undesirable

behavior

Ensure complete

and accurate

financial records

and reporting

Meet requirements 6

of SOX 406

$\begin{array}{lll}\text { Bring to the } 15 & 17 \\ \text { attention of the } & \end{array}$

audit committee of

the board of

directors

Bring to the $12 \quad 17$

general counsel or

chief legal officer

Hot line or 4
anonymous and
confidential
reporting system

\begin{tabular}{|c|c|c|c|c|}
\hline \multirow{5}{*}{$\begin{array}{l}\text { Consequence of } \\
\text { Violations }\end{array}$} & \multirow{5}{*}{22} & $\begin{array}{l}\text { Termination } \\
\text { employment }\end{array}$ & 20 & 22 \\
\hline & & $\begin{array}{l}\text { Disciplinary } \\
\text { actions }\end{array}$ & 20 & 20 \\
\hline & & $\begin{array}{l}\text { Civil or criminal } \\
\text { penalties }\end{array}$ & 6 & 6 \\
\hline & & $\begin{array}{l}\text { Investigate and } \\
\text { evaluate at the } \\
\text { proper levels }\end{array}$ & 7 & 8 \\
\hline & & $\begin{array}{l}\text { Audit committee } \\
\text { conducts } \\
\text { investigation }\end{array}$ & 5 & 5 \\
\hline
\end{tabular}




\begin{tabular}{|c|c|c|c|c|c|}
\hline & & & $\begin{array}{l}\text { Report to law } \\
\text { enforcement }\end{array}$ & 4 & 4 \\
\hline \multirow{3}{*}{ Code Waivers } & \multirow{3}{*}{19} & \multirow{3}{*}{21} & $\begin{array}{l}\text { Disclosed as } \\
\text { required by law or } \\
\text { regulation }\end{array}$ & 10 & 10 \\
\hline & & & $\begin{array}{l}\text { Approved by the } \\
\text { board of directors }\end{array}$ & 8 & 8 \\
\hline & & & $\begin{array}{l}\text { Approved by the } \\
\text { audit committee of } \\
\text { the board of } \\
\text { directors }\end{array}$ & 7 & 7 \\
\hline
\end{tabular}

Prohibition on
Retaliation for 12
Reporting Code
Violations

Officer

Signature or 11

Certification

\begin{tabular}{|c|c|c|c|c|c|}
\hline \multirow{3}{*}{$\begin{array}{l}\text { Code } \\
\text { Amendments }\end{array}$} & \multirow{3}{*}{8} & \multirow{3}{*}{8} & Approval & 7 & 8 \\
\hline & & & COE Date & 5 & 5 \\
\hline & & & $\begin{array}{l}\text { Disclosure } \\
\text { amendments }\end{array}$ & of 6 & 6 \\
\hline $\begin{array}{l}\text { Guidance for } \\
\text { Officers }\end{array}$ & 4 & 5 & & & \\
\hline $\begin{array}{l}\text { Code } \\
\text { Availability }\end{array}$ & 1 & 1 & & & \\
\hline Code Ownership & 2 & 2 & & & \\
\hline
\end{tabular}

Our first major code category relates to the title of the financial codes of ethics. The first indication that these financial codes of ethics differ from general codes of ethics is their titles. Although the title used for this special purpose code of ethics statement varies, the title of the code clearly identifies the primary corporate officers to whom the code applies in 27 of the codes $(93.10 \%)$. In 20 of these 29 codes $(68.96 \%)$ the title includes the word "senior" to emphasize that it is applicable to senior officers and/or senior financial officers. In 9 of the codes $(31.03 \%)$, the CEO (Chief Executive Officer) also is explicitly referenced in the title as 
one of the persons to whom the code applies in addition to financial officers. Appendix 2 includes a complete list of the financial code of ethics titles used by our sample firms.

Based on our examination of the financial codes of ethics, it is apparent that several of the major categories within the codes are more commonly included than others. Other than the category of "Title", only two other categories are included in all of the codes that we examine: (1) "Covered Employees" and (2) "Officer Responsibilities." Regarding "Covered Employees," $27(93.10 \%)$ of the codes state that the CEO must adhere to the code, 19 $(65.52 \%)$ hold the principal accounting officer/controller accountable for abiding by the code, $18(62.06 \%)$ state that the CFO must abide by the code and $14(48.28 \%)$ require that senior financial officers adhere to the code.

Twenty-eight $(96.55 \%)$ of the codes hold the covered employees responsible for ensuring "full, fair, accurate, timely and understandable disclosures", while 24 (82.76\%) codes state that covered employees have responsibilities related to "laws, rules and regulations", and 23 (79.31\%) codes expect "honest and ethical conduct" of covered employees. Since these three items are defined by SOX 406 as major components of a code of ethics, we are surprised that some of the financial codes of ethics we examined do not address these areas.

Seventeen $(58.62 \%)$ of the codes state that the covered employees should act as "role models and promote ethical behavior". This is consistent with the importance placed on the "tone at the top" as first discussed by the Treadway Commission (National Commission on Fraudulent Financial Reporting, 1987) and examined in ethics literature (Schwartz et al., 2005; Johnson et al., 2012, Schwartz, 2013; Shafer, 2015;). Thirteen (44.83\%) of the codes specify concerns that covered employees are expected to communicate if they are aware of these issues within their firm.

Twenty-four $(82.76 \%)$ of the codes contain a section describing the purpose of the financial code of ethics. The most commonly stated purpose of the financial code of ethics is to supplement the general code of ethics ( 13 codes, $44.83 \%$ ), followed by the stated purposes of "promoting honesty and ethics" (10 codes, $34.48 \%$ ), "ensuring or promoting compliance with laws and regulations" (7 codes, 24.14\%), "preventing undesirable behavior" (7 codes, $24.14 \%$ ), "ensuring complete and accurate financial records and reporting" (6 codes, 20.69\%), and meeting the requirements of SOX 406 (6 codes, 20.69\%). It is not unexpected to find sections of the codes relating to honesty and ethics, compliance with laws and regulations, complete and accurate accounting records and reporting, and SOX 406 since SOX 406 probably is a major impetus behind the financial codes of ethics and contains language referencing these purposes. However, it is notable that many firms state that their code of ethics for senior financial officers (financial code of ethics) is a supplement, not a replacement, of their general code of ethics and several firms also assert that their financial code of ethics is designed to prevent undesirable behavior by the covered employees.

\subsection{Appearance and Weights of Categories Within the Codes}

In addition to determining which categories and sub-categories appear in each code, we also track the number of times a category or sub-category is referenced within the codes. We use 


\section{Mll Macrothink}

International Journal of Accounting and Financial Reporting

ISSN 2162-3082

2019, Vol. 9, No. 1

the number of references as a proxy for the weight or importance given to a topic within the codes we examined. We acknowledge that this is an imperfect measure of the importance of a category or sub-category, but believe that it is a reasonable measure of the importance that the companies assigned to those areas.

The category having the most weight in the financial codes of ethics we examined is "Officer Responsibilities" with 286 references in all 29 (100\%) of the codes. The category with the second highest weight is "Purpose" with a total of 65 references in $24(83 \%)$ of the codes, while "Prohibited Activities" has the third highest weight with 58 references in $25(86 \%)$ of the codes. The fourth most referenced category is "Covered Employees" which is referenced 30 times and found in $29(100 \%)$ of the codes. The other categories we examined are referenced one or fewer times in each of the codes. Table 1 contains a listing of the 14 major categories we identified within the codes we examined, the number of codes that contain each category and the number of times the codes reference each category. See Figure 1 for an illustration of the hierarchical relationship between the major categories in our study and the related level-1 and level-2 subcategories.

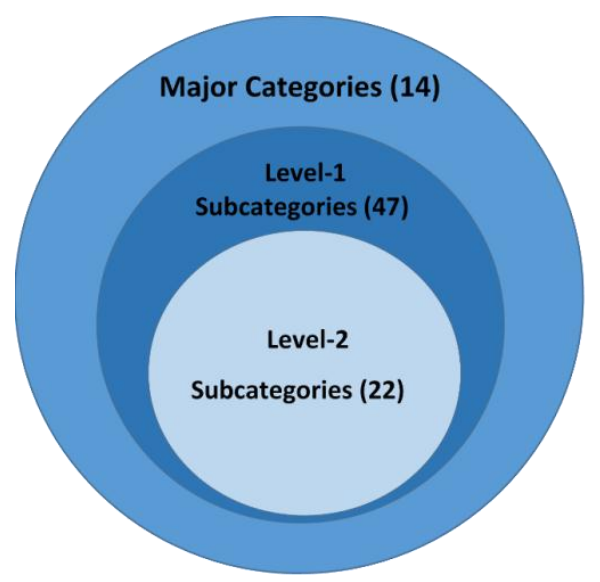

Figure 1. Number of major categories and subcategories of financial codes of ethics

\subsection{Sub-Categories Aligned With SOX 406}

Within the fourteen major categories of the codes, we identify a number of level-1 sub-categories. The level-1 subcategory that appears in the largest number of the codes is the "Full, fair, accurate, timely and understandable disclosures" subcategory of "Officer Responsibilities which appears in $28(97 \%)$ of the codes and is referenced 32 times. Since SOX 406 lists this as one of the primary objectives of a code of ethics, this result is not unexpected and is higher than the results of previous studies, e.g., White and Montgomery (1980) and Cressy and Moore (1983) found that only approximately 50\% of the general codes of ethics they examine mention the integrity of financial records while Benson (1989) found that only a third of the general codes of ethics examined mention accounting records and Lugli, Kocollari and Nigosolari (2009) found that $72 \%$ of the general codes of ethics in their study had provisions related to the integrity of financial records. 


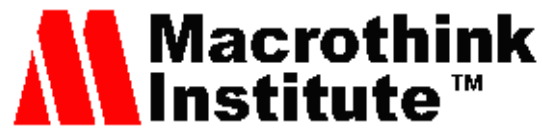

International Journal of Accounting and Financial Reporting

ISSN 2162-3082

2019, Vol. 9, No. 1

The "Laws, Rules and Regulations" subcategory of "Officer Responsibilities" is another heavily incorporated sub-category with a total of 33 references in 24 (83\%) of the codes. Again, this is an anticipated outcome since "compliance with applicable governmental rules and regulations" is another of the primary objectives of a code of ethics listed in SOX 406 and is higher than what was found in previous studies, e.g., White and Montgomery (1980) [67\%] and Lugli, Kocollari and Nigosolari (2009) [55\%]. SOX 406 also explicitly mentions "honest and ethical conduct" as one of the primary components of a code of ethics and, as expected, this subcategory of "Officer Responsibilities" appears in 23 (79\%) of the codes and is referenced 30 times. This is slightly lower that the findings of previous studies. White and Montgomery (1980) found that $80 \%$ of the general codes of conduct they examined contained a general statement of ethics and Lugli, Kocollari and Nigosolari (2009) found that $86 \%$ of the general codes of conduct in their study discuss honesty. Consequently, as expected, the three primary objectives of codes of ethics defined by SOX 406 are heavily emphasized and found in most of the financial codes of ethics examined in this study.

\subsection{Other Areas of the Codes}

In addition to the components of the codes that are related to SOX 406, other areas of financial officer behavior are discussed in the financial codes of ethics. Several sub-categories of "Prohibited Activities" are found in the majority of the codes. Sections discussing "conflicts of interest" are found in $21(72 \%)$ of the codes and are referenced 22 times which is near the low end of the range found in previous studies that we reviewed, $69 \%-95.3 \%$. Twenty (69\%) of the codes discuss "consequences of violations" and list "termination of employment" and "disciplinary actions" as consequences of violations of the financial code of ethics which is higher than what was found in studies that we reviewed, $42 \%-59 \%$. It is surprising that only 7 codes (24\%) explicitly discuss the need for code violations to be investigated and evaluated at the proper levels within the organization (8 references). Even fewer codes (6 codes, $21 \%$ ) discuss civil or criminal penalties for code violators (6 references) and only 4 codes (14\%) mention the possibility of reporting code violations to law enforcement agencies (4 references). Only 2 codes (7\%) state that all relevant information should be considered during investigation of code violations.

Although it would seem that corporations would expect that their financial code of ethics to apply to all senior financial officers, without exception, more than half of the codes we examined (19 codes, 66\%) allow for waivers of the code. Eight (26\%) of the codes allow for waivers approved by the board of directors while seven $(24 \%)$ of the codes allow for waivers approved by the audit committee of the board of directors. Ten (34\%) of the codes explicitly state that any code waivers must be appropriately disclosed as required by laws or regulations.

Several codes contain other important categories. For example, twelve codes (41\%) expressly prohibit retaliation against employees that report code violations. Eleven codes (38\%) require officer signatures or certification and eight codes (28\%) discuss code amendments. Interestingly, only two codes $(6 \%)$ specify who within the organization "owns" the code and only one code $(3 \%)$ discusses availability of the code. 


\section{Mll Macrothink}

International Journal of Accounting and Financial Reporting ISSN 2162-3082

Table 2 Expands upon our results reported in Table 1 by summarizing the level-2 subcategories and listing the most referenced level-2 code subcategories and their associated level-1 code subcategories (Note 3).

Table 2. The most common financial code of ethics level-1 and level-2 subcategories

\begin{tabular}{|c|c|c|c|c|c|}
\hline $\begin{array}{l}\text { Level-1 } \\
\text { Subcategories }\end{array}$ & $\begin{array}{l}\text { \# of FCOE } \\
\text { Containing }\end{array}$ & $\begin{array}{l}\# \text { of } \\
\text { References }\end{array}$ & $\begin{array}{l}\text { Level-2 } \\
\text { Subcategories }\end{array}$ & $\begin{array}{l}\text { \# of FCOE } \\
\text { Containing }\end{array}$ & $\begin{array}{l}\# \text { of } \\
\text { References }\end{array}$ \\
\hline $\begin{array}{l}\text { Full, fair, } \\
\text { accurate, timely } \\
\text { and } \\
\text { understandable } \\
\text { disclosures }\end{array}$ & 28 & 32 & $\begin{array}{l}\text { Ensure the full, } \\
\text { fair disclosures in } \\
\text { the reports and } \\
\text { documents } \\
\text { submitted to the } \\
\text { SEC and other } \\
\text { public } \\
\text { communications }\end{array}$ & 21 & 22 \\
\hline $\begin{array}{l}\text { Laws, rules and } \\
\text { regulations }\end{array}$ & 24 & 33 & $\begin{array}{l}\text { Compliance with } \\
\text { laws, rules and } \\
\text { regulations }\end{array}$ & 23 & 29 \\
\hline \multirow[t]{3}{*}{$\begin{array}{l}\text { Conflicts } \\
\text { interest }\end{array}$} & 21 & 22 & $\begin{array}{l}\text { Definition of } \\
\text { conflict of interest }\end{array}$ & 7 & 8 \\
\hline & & & $\begin{array}{ll}\text { Required } & \\
\text { disclosure } & \text { of } \\
\text { conflicts } & \text { of } \\
\text { interest } & \end{array}$ & 7 & 7 \\
\hline & & & $\begin{array}{ll}\text { Examples } & \text { of } \\
\text { conflicts } & \text { of } \\
\text { interest } & \end{array}$ & 6 & 17 \\
\hline \multirow[t]{3}{*}{$\begin{array}{l}\text { Communication } \\
\text { of issues }\end{array}$} & 20 & 145 & $\begin{array}{l}\text { Communicate } \\
\text { issues to } \\
\text { responsible party }\end{array}$ & 16 & 38 \\
\hline & & & $\begin{array}{l}\text { Any significant } \\
\text { deficiencies in } \\
\text { internal control } \\
\text { design that will } \\
\text { affect the } \\
\text { financial records }\end{array}$ & 9 & 9 \\
\hline & & & $\begin{array}{l}\text { Any violations of } \\
\text { laws, rules or }\end{array}$ & 8 & 9 \\
\hline
\end{tabular}




\begin{tabular}{|c|c|c|c|c|c|}
\hline & & & \multicolumn{3}{|l|}{ regulations } \\
\hline & & & $\begin{array}{l}\text { Unethical } \\
\text { behavior }\end{array}$ & 8 & 9 \\
\hline & & & $\begin{array}{l}\text { Any conflict of } \\
\text { interest }\end{array}$ & 8 & 8 \\
\hline & & & $\begin{array}{l}\text { Any fraud that } \\
\text { involves } \\
\text { management or } \\
\text { staff involved in } \\
\text { financial } \\
\text { reporting, } \\
\text { disclosure or } \\
\text { internal controls }\end{array}$ & 7 & 7 \\
\hline & & & $\begin{array}{l}\text { Any information } \\
\text { that may lead to } \\
\text { material } \\
\text { misstatement }\end{array}$ & 5 & 5 \\
\hline \multirow[t]{3}{*}{$\begin{array}{l}\text { Role model and } \\
\text { promoting } \\
\text { ethical behavior }\end{array}$} & 17 & 26 & $\begin{array}{l}\text { Proactively } \\
\text { promote ethical } \\
\text { behavior }\end{array}$ & 12 & 15 \\
\hline & & & $\begin{array}{l}\text { Be a positive } \\
\text { example }\end{array}$ & 5 & 5 \\
\hline & & & Share knowledge & 4 & 4 \\
\hline Insider trading & 13 & 17 & $\begin{array}{l}\text { Material } \\
\text { non-public } \\
\text { information } \\
\text { should not be } \\
\text { used for trading } \\
\text { securities }\end{array}$ & 3 & 7 \\
\hline \multirow[t]{2}{*}{$\begin{array}{l}\text { Protecting } \\
\text { assets }\end{array}$} & 10 & 11 & $\begin{array}{l}\text { Responsible use } \\
\text { and control over } \\
\text { all assets and } \\
\text { resources }\end{array}$ & 10 & 10 \\
\hline & & & $\begin{array}{l}\text { Protecting } \\
\text { information }\end{array}$ & 3 & 3 \\
\hline Confidentiality & 9 & 12 & Not & 8 & 8 \\
\hline
\end{tabular}




\begin{tabular}{|c|c|c|c|c|c|}
\hline & & & $\begin{array}{l}\text { confidential } \\
\text { information for } \\
\text { personal gains }\end{array}$ & & \\
\hline & & & $\begin{array}{l}\text { Maintain } \\
\text { confidentiality of } \\
\text { non-public } \\
\text { proprietary } \\
\text { information }\end{array}$ & 7 & 9 \\
\hline \multirow[t]{2}{*}{$\begin{array}{l}\text { Code } \\
\text { amendments } \\
\text { approved by }\end{array}$} & 7 & 8 & Board of directors & 4 & 4 \\
\hline & & & $\begin{array}{l}\text { Audit committee } \\
\text { of the board of } \\
\text { directors }\end{array}$ & 2 & 2 \\
\hline
\end{tabular}

Since all of the firms in our study are publicly-traded, it is not surprising that $21(72 \%)$ of the FCOEs contain an expectation of full and fair disclosure in reports and documents submitted to the SEC and other public communications, which is slightly lower than the expectation of compliance with laws, rules and regulations that is referenced 29 times in 23 codes (79\%). Most of the codes we examined do not provide specific guidance regarding conflicts of interest. However, a minority of codes includes definitions of conflict of interest (7 codes, $24 \%$ ), state that conflicts of interest must be disclosed (7 codes, 24\%) and give examples of conflicts of interest (6 codes, 21\%). This result may be due to the fact that many firms include sections regarding conflicts of interest in their general code of ethics, as mentioned previously. In contrast, a majority of codes require that officers communicate significant issues to a responsible party (16 codes, $55 \%, 38$ references). Significant issues that warrant communication include significant deficiencies in internal control over financial reporting $(9$ codes, $31 \%$ ), violations of laws, rules or regulations ( 8 codes, $28 \%$ ), unethical behavior ( 8 codes, $28 \%$ ), conflicts of interest ( 8 codes, $28 \%$ ), fraud that involves management or staff involved in financial reporting, disclosure or internal controls (7 codes, 24\%) and any information related to material misstatements (5 codes, 17\%).

Most of the codes we examined do not expect the covered officers either to proactively promote ethical behavior, with only 12 codes $(41 \%)$ requiring this behavior. Likewise, only 5 codes $(17 \%)$ desire officers to be a positive role model while 4 codes (14\%) expect officers to share their knowledge with others in the organization. It is surprising that only 10 codes $(35 \%)$ require officers to responsibly use and control organizational assets and resources. An even more unexpected result, given the importance of information to the modern firm, is that only 3 codes (10\%) expect officers to protect organizational information. However, more firms expect officers to refrain from using confidential information for personal gains (8 codes, $28 \%$ ) and to maintain confidentiality of non-public proprietary information (7 codes, $24 \%$ ). Finally, a small minority of codes contain the requirement that code amendments be approved 
by the board of directors ( 4 codes, $14 \%$ ) or the audit committee of the board of directors ( 2 codes, $7 \%$ ).

\section{Discussion and Conclusions}

Section 406 of the Sarbanes-Oxley Act requires that publicly-traded corporations disclose whether they have adopted a code of ethics that covers their senior finance officers including the principal financial officer and the principal accounting officer. Alternatively, corporations that do not have a code of ethics designed for senior financial officers may choose to specify that their general code of ethics covers those officers. Regardless of whether the senior financial officers are covered by a specific code of ethics or a general code of ethics, SOX 406 suggests that the code of ethics address three areas: (1) honest and ethical conduct, (2) full, fair, accurate, timely, and understandable disclosure in the periodic reports, and (3) compliance with applicable governmental rules and regulations. However, developing codes of ethics gives corporations the opportunity to enumerate ethical expectations for their senior finance officers that go beyond the SOX 406 requirements. Our results indicate that the corporations whose codes of ethics were examined in this study typically go far beyond the SOX requirements and delineate responsibilities of senior financial officers as well as prohibited activities. Full, fair, accurate, timely and understandable disclosures and compliance with applicable laws and regulation are heavily emphasized by these codes of ethics as are and honest and ethical conduct and communication of issues by the senior financial officers. From our analysis, it also is apparent that most of the companies expect their senior financial officers to be positive role models for other employees and to actively promote ethical behavior.

Most of the financial codes of ethics we examined also contain discussion of prohibited activities, primarily conflicts of interest and insider trading. Penalties for violations of the codes also are discussed with most of the codes listing termination of employment and other disciplinary actions as part of the response to code violations. The majority of the codes also contain provisions that require senior financial officers to report any violations of the code of ethics of which they are aware.

However, we find that many of the codes in our study do not discuss important issues. Less than half of the codes we examine address the issue of waivers of the code of ethics or prohibit retaliation for reporting code violations. Similarly, only a minority of the codes in our study require officer signatures or certification and less than a third discuss the process for amending the code of ethics. Finally, very few codes provide guidance for officers who seek clarification of the code, discuss who within the company is considered the "owner" of the code, or disclose where interested parties can locate the code.

Comparing our results to the findings of previous studies that examined general codes of ethics, we find that full, fair, accurate, timely and understandable disclosures and the integrity of financial records is much more heavily emphasized in the financial codes of ethics we examined as is compliance with applicable governmental rules and regulations, and consequences for violations of the code. This result may be due to the fact that the responsibilities of the $\mathrm{CEO}$ and senior financial officers generally encompass financial 
reporting and ensuring compliance with laws and regulations. The increased emphasis on consequences of violations of the code may be a reflection of this fact.

The financial codes of conduct we examine discuss honest and ethical conduct on par with the general codes of conduct in the previous studies we reviewed. However, the discussion of conflicts of interest in the financial codes of ethics we examine appear in only $72 \%$ of the codes, which is near the low end of the range found in previous studies that we reviewed, 69\%-95.3\%. Additional specific guidance on conflicts of interest appears in very few of the financial codes of ethics we examine possibly because additional guidance may be provided in general codes of conduct.

Codes of ethics can be powerful tools for promoting positive behavior and discouraging undesirable behavior among employees. Our study results reflect the fact that most public corporations realize the importance of holding senior financial officers accountable for compliance with a code of ethics. However, many publicly-traded firms choose to hold senior financial officers accountable for compliance with their general code of ethics instead of with a financial code of ethics designed specifically for the senior financial officers. Future research needs to be conducted to determine if a separate financial code of ethics is more effective than a general code of ethics in promoting ethical behavior and discouraging undesirable behavior among senior financial officers. The prevalence of financial codes of ethics also may vary across industries. For example, Etheridge and Hsu (2018) find that only four of the ten largest oil and gas firms traded on U.S. stock exchanges have a separate financial code of ethics for their CEO and senior financial officers. Other industries may have higher or lower rates of usage of financial codes of ethics. Additional future research can examine the differences of prevalence and use of financial codes of ethics across industries.

\section{References}

Adelstein, J., \& Clegg, S. (2016). Code of Ethics: A Stratified Vehicle for Compliance. Journal of Business Ethics, 138, 53-66.

Ahluwalia, S., Ferrell, O. C., Ferrell, L., \& Rittenburg, T. L. (2018). Sarbanes-Oxley Section 406 Code of Ethics for Senior Financial Officers and Firm Behavior. Journal of Business Ethics, 151, 693-705.

Benson, G. C. S. (1989). Codes of Ethics. Journal of Business Ethics, 8(5), 305-319.

Bondy, K., Matten, D., \& Moon, J. (2004). The Adoption of Voluntary Codes of Conduct in MNCs: A Three-Country Comparative Study. Business \& Society Review, 109(4), 449-477.

Cressey, D. R., \& Moore, C. A. (1983). Managerial Values and Corporate Codes of Ethics. California Management Review, 25(4), 53-77.

Etheridge, H. L., \& Hsu, K. H. Y. (2018). Ethical Reporting and Compliance: SOX 406 and Large Oil and Gas Corporations Listed on U.S. Stock Exchanges. Oil, Gas \& Energy Quarterly, 67(1), 97-113. 


\section{$\triangle 1$ Macrothink}

International Journal of Accounting and Financial Reporting

ISSN 2162-3082

2019, Vol. 9, No. 1

Farrell, B. J., Cobbin, D. M., \& Farrell, H. M. (2002). Codes of ethics: Their evolution, development and other controversies. Journal of Management Development, 21(2), 152-163.

Frankel, M. S. (1989). Professional Codes: Why, How, and with What Impact?. Journal of Business Ethics, 8(2-3), 109-115.

Garegnani, G. M., Merlotti, E. P., \& Russo, A. (2015). Untangling the antecedents of code of ethics quality: does corporate governance matter?. Corporate Governance, 15(5), 607-622.

Johnson, D. G., \& Snapper, J. W. (1985). Ethical issues in the use of computers. Belmont, Calif.: Wadsworth Pub. Co.

Johnson, E. N., Fleischman, G. M., Valentine, S., \& Walker, K. B. (2012). Managers' Ethical Evaluations of Earnings Management and Its Consequences. Contemporary Accounting Research, 29(3), 910-927.

Kaptein, M., \& Schwartz, M. S. (2008). The Effectiveness of Business Codes: A Critical Examination of Existing Studies and the Development of an Integrated Research Model. Journal of Business Ethics, 77(2), 111-127.

Kaye, B. N. (1992). Codes of Ethics in Australian Business Corporations. Journal of Business Ethics, 11(11), 857-862.

Langlois, C. C., \& Schlegelmilch, B. B. (1990). Do Corporate Codes of Ethics Reflect National Character? Evidence from Europe and the United States. Journal of International Business Studies, 21(4), 519-539.

Murphy, P. E. (1989). Creating Ethical Corporate Structures. Sloan Management Review, 30(2), 81-87.

National Commission on Fraudulent Financial Reporting. (1987). The Report of the National Commission on Fraudulent Financial Reporting. Retrieved from https://www.coso.org/Documents/NCFFR.pdf

Robin, D., Giallourakis, M., David, F. R., \& Moritz, T. E. (1989). A Different Look at Codes of Ethics. Business Horizons, 32(1), 66-73.

Schwartz, M. S. (2013). Developing and sustaining an ethical corporate culture: The core elements. Business Horizons, 56(1), 39-50.

Schwartz, M. S., Dunfee, T. W., \& Kline, M. J. (2005). Tone at the Top: An Ethics Code for Directors?. Journal of Business Ethics, 58(1-3), 79-100.

Shafer, W. E. (2015). Ethical Climate, Social Responsibility, and Earnings Management. Journal of Business Ethics, 126(1), 43-60.

Sharbatoghlie, A., Mosleh, M., \& Shokatian, T. (2013). Exploring trends in the codes of ethics of the Fortune 100 and Global 100 corporations. Journal of Management Development, $32(7), 675-689$. 


\section{Ml Macrothink}

International Journal of Accounting and Financial Reporting

ISSN 2162-3082 2019, Vol. 9, No. 1

Vinten, G. (1990). Business Ethics Busybody or Corporate Conscience. Managerial Auditing Journal, 5(2), 4-11.

White, B. J., \& Montgomery, B. R. (1980). Corporate Codes of Conduct. California Management Review, 23(2), 80-87.

Wood, G. (2000). A Cross Cultural Comparison of the Contents of Codes of Ethics: USA, Canada and Australia. Journal of Business Ethics, 25(4), 287-298.

\section{Notes}

Note 1. A company that is subject to the reporting requirements of Section 13(a) or 15(d) of the Securities Exchange Act of 1934.

Note 2. This includes "...discussion of off-[book] accounts, false or misleading reports and supporting documents, and candor with internal and independent auditors." (Cressey \& Moore, 1983).

Note 3. Note that not all level 1 subcategories have associated level 2 categories. Table 2 lists only the level 1 subcategories with associated level 2 subcategories.

\section{Appendix}

Appendix 1. Corporations in the Study

\begin{tabular}{|c|c|c|c|c|}
\hline Company Name & $\begin{array}{l}\text { Primary } \\
\text { SIC Code }\end{array}$ & $\begin{array}{l}\text { Primary SIC } \\
\text { Description }\end{array}$ & $\begin{array}{l}\text { Employees } \\
\text { (Thousands) }\end{array}$ & $\begin{array}{l}\text { Total } \\
\text { Assets } \\
\text { (Millions) }\end{array}$ \\
\hline $\begin{array}{l}\text { Affiliated Managers } \\
\text { Grp Inc }\end{array}$ & 6282 & Investment Advice & 3.2 & $\$ 7,784.80$ \\
\hline Alcoa Inc & 3350 & $\begin{array}{l}\text { Rolling \& Draw Nonfer } \\
\text { Metal }\end{array}$ & 60 & $\$ 36,528.00$ \\
\hline Amgen Inc & 2836 & $\begin{array}{l}\text { Biological Pds, } \quad \text { Ex } \\
\text { Diagnstics }\end{array}$ & 17.9 & $\$ 71,576.00$ \\
\hline Autodesk Inc & 7372 & Prepackaged Software & 9.5 & $\$ 5,515.30$ \\
\hline Autozone Inc & 5531 & $\begin{array}{l}\text { Auto and Home Supply } \\
\text { Stores }\end{array}$ & 81 & $\$ 8,102.35$ \\
\hline Boeing Co & 3721 & Aircraft & 161.4 & $\$ 94,408.00$ \\
\hline
\end{tabular}




$\begin{array}{lclll}\begin{array}{l}\text { Bristol-Myers } \\ \text { Squibb Co }\end{array} & 2834 & \begin{array}{l}\text { Pharmaceutical } \\ \text { Preparations }\end{array} & 25 & \$ 31,748.00 \\ \text { Cisco Systems Inc } & 3576 & \begin{array}{l}\text { Computer } \\ \text { Communication Equip }\end{array} & 71.833 & \begin{array}{l}\$ 113,481.0 \\ 0\end{array}\end{array}$

Conagra Foods Inc $2000 \quad$ Food and Kindred 32.9

$\$ 17,542.20$

Products

D R Horton Inc

1531

Operative Builders

6.23

$\$ 11,151.00$

Eastman Chemical 2821

Plastics,

15

$\$ 15,611.00$

Co

Resins,Elastomers

Eversource Energy

4931

Electric \& Other Serv 7.943

$\$ 30,580.31$

Comb

Flir Systems Inc

3812

Srch, Det, Nav, Guid, 3.003

$\$ 2,406.40$

Aero Sys

Genuine Parts Co 5013

Motor Veh Suply, New 39.6

$\$ 8,144.77$

Pts-Whsl

Leggett \& Platt Inc

2510

Household Furniture

20

$\$ 2,967.60$

Level

34813

Phone

Comm

Ex 12.5

$\$ 24,145.00$

Communications

Radiotelephone

Inc

Lkq Corp

5010

Motor

Veh

Parts, 31.1

$\$ 5,647.84$

Supply-Whsl

Monsanto Co

100

Agriculture

25.5

$\$ 21,920.00$

Production-Crops

News Corp

2711

Newspaper:Pubg, Pubg \& 25

$\$ 15,093.00$

Print

Paccar Inc

3711

Motor Vehicles \& Car 23

$\$ 21,109.80$

Bodies

Ralph Lauren Corp

2320

Mens, Boys Frnsh, Work 26

$\$ 6,213.00$ 
Clthng

\begin{tabular}{|c|c|c|c|c|c|}
\hline \multicolumn{2}{|c|}{ Sealed Air Corp } & 2670 & $\begin{array}{l}\text { Convrt Papr, Paprbrd, Ex } \\
\text { Boxes }\end{array}$ & 23 & $\$ 7,426.00$ \\
\hline \multicolumn{2}{|c|}{ Starbucks Corp } & 5812 & Eating Places & 238 & $\$ 12,446.10$ \\
\hline \multicolumn{2}{|c|}{ Time Warner Inc } & 4888 & Diversified Multi-Media & 24.8 & $\$ 63,848.00$ \\
\hline $\begin{array}{l}\text { Universal } \\
\text { Svcs Inc }\end{array}$ & Health & 8062 & $\begin{array}{l}\text { Gen Med \& Surgical } \\
\text { Hospitals }\end{array}$ & 74.6 & $\$ 9,634.11$ \\
\hline Viacom Inc & & 4833 & $\begin{array}{l}\text { Television } \\
\text { Station }\end{array}$ & 9.2 & $\$ 22,217.00$ \\
\hline Visa Inc & & 6099 & $\begin{array}{l}\text { Functions Rel To Dep } \\
\text { Bkg,Nec }\end{array}$ & 11.3 & $\$ 40,236.00$ \\
\hline $\begin{array}{l}\text { Walgreens } \\
\text { Alliance Inc }\end{array}$ & Boots & 5912 & Drug \& Proprietary Stores & 360 & $\$ 68,782.00$ \\
\hline $\begin{array}{l}\text { Zimmer } \\
\text { Holdings Inc }\end{array}$ & Biomet & 3842 & $\begin{array}{l}\text { Ortho, Prosth, Surg Appl, } \\
\text { Suply }\end{array}$ & 17.5 & $\$ 27,219.50$ \\
\hline
\end{tabular}

Appendix 2. Financial code of ethics titles

Title

Code of Ethics for Senior Financial Officers (Executives)

Code of Ethics for (the) Chief (Principal, Senior) Executive Officer and 4 Senior Financial Officers

Code of Ethics for CEO (Chief Executive) and Senior Financial Officers

Code of Conduct and Ethics for Senior Financial Officers

Code of Conduct for Finance

Code of Ethical Conduct for CEO, CFO and Senior Financial Officers 
Code of Ethics for CEO, COO, CFO and Finance Leaders -

Code of Ethics for Financial Officers

Code of Ethics for Senior Corporate Officers

Code of Ethics for Senior Executive and Financial Officers

Code of Ethics for Senior Financial Executives

Code of Ethics for the CEO, CFO and Other Financial Professionals

Financial Code of Ethics

Financial Officer Code of Ethics

Financial Officers' Code of Ethics and Business Conduct

Special Ethics Obligations for Senior Financial Officers

Supplemental Code of Ethics for Senior Financial Officers

1

\section{Copyright Disclaimer}

Copyright for this article is retained by the author(s), with first publication rights granted to the journal.

This is an open-access article distributed under the terms and conditions of the Creative Commons Attribution license (http://creativecommons.org/licenses/by/4.0/) 